\title{
Discussion: Bored pile design in stiff clay l: codes of practice
}

Paul J. Vardanega MEngSc, PhD, MIEAust, M.ASCE Research Associate, Department of Engineering, University of Cambridge, UK

Ekaterina Kolody MSC

Geotechnical Engineer, Arup, London, UK

Stuart H. Pennington BEng, BSurv, CEng, MICE Senior Geotechnical Engineer, Arup, London, UK
Paul R. J. Morrison MSC, DIC, PhD, CEng, MIEI

Director, Arup, London, UK

Brian Simpson OBE, FREng, MA, PhD, FICE

Arup Fellow, Arup, London, UK

Nick O’Riordan PE CEng

Arup, London, UK

Brandon Kluzniak PE

Arup, San Francisco, USA

\section{Contribution by Nick O'Riordan and Brandon Kluzniak}

Vardanega et al. (2012) have produced an interesting examination of various code approaches to the design of bored piles in stiff clay (Vardanega et al., 2012). Included in the codes considered was the Aashto (2007) load and resistance factor design (LRFD) bridge design specification document, and strict application of that document produced an equivalent lumped factor of safety, $F$, of between 3.41 and $3 \cdot 85$, using undrained strength data. These are by far the highest values of $F$ found by the authors, and imply that the Aashto design method will produce a larger, less efficient pile than other codes considered.

Pile design practice in the USA varies from state to state, and some states have published amendments to Aashto (2007) to take account of local conditions. In California for example, Caltrans (2011), at Table 10.5.5.2.4-1 for bored ('drilled') pile construction, replaces the Aashto resistance factor on pile shaft resistance of 0.45 with 0.7 , and the Aashto resistance factor on pile base resistance of $0 \cdot 4$ with $0 \cdot 5$. Caltrans (2011) cites engineering judgement and past design practice as the primary reasons for these amendments. Caltrans (2011) stresses the importance of construction quality control, and states that the 'full effectiveness of the tip resistance should only be permitted when cleaning of the bottom of the drilled shaft is specified and can be acceptably completed before concrete is placed.'

Using the full Caltrans (2011) amendments, we calculate a value of $F$ of 2.58 , which falls perhaps fortuitously within the range 2.43 to 2.66 calculated using Eurocode 7 .

Readers may be somewhat surprised at Caltrans' use of, in effect, an equivalent $\alpha$ value of 0.7 for a stiff clay. This value can be related to a reliability index, $\beta$, that represents the number of standard deviations between the mean safety margin and the failure limit (Paikowsky, 2004). Using this approach, an $\alpha$ value of 0.7 would imply a $\beta$ value of about 2.5 , rather than about 3.5 if using the lower, Aashto-specified resistance factors.

However, in California it is often the case that the governing load case is from short-term, rapid loading from seismic action, in which a stiff clay could exhibit higher stiffness and strength. Guha (1995) showed an increase in stiffness and strength, for the Old Bay Clay contemplated by the authors, of approximately $5 \%$ per order-ofmagnitude increase in strain rate over that produced from slow undrained strength testing in a conventional laboratory. The high $\alpha$ factor of 0.7 may in part reflect an allowance for such rate effects.

Finally, we draw the authors' attention to FHWA (2010), in which Aashto (2007) is rigorously reviewed. Great stress is given to pile load testing and back-analysis in order to provide continuing refinement of parameters for the design of piles.

\section{Authors' reply}

We welcome the clarification from the discussers regarding the Caltrans modifications to the Aashto design approach for piles. It seems that the USA may be no more 'united' than Europe in terms of geotechnical standards. In the original paper (Vardanega et al., 2012), a review was undertaken to compare the different design approaches (DA1, DA2 and DA3) in Eurocode 7. A similar comparative study could be undertaken with the different modifications or annexes to the Aashto design code from different jurisdictions within the United States. It is interesting to note that using the Caltrans modification of Aashto the pile design would be fairly similar to that obtained using the Eurocode.

The discussers cite the work of Paikowsky (2004), which suggests that the partial factors for pile design can be determined from statistical calibration - again based on data. This implies that the database used to calibrate any partial factor set is 'representative' of the designs that will be carried out under its auspices. Eurocode 7 assigns partial factors based on the experience of experts, who would have access to various databases, but it does not claim to have a load-test database that represents pile designs for the whole of Europe. The key is to have access to a database that is representative of the designs that will be done under the auspices of the code.

Other codes also facilitate risk analysis, but not using explicit statistical procedures. Vardanega et al. (2012) reviewed the approaches described in AS2159-2009 (Standards Australia, 2009) and Poulos (2004), where the code drafters set limits on 
the geotechnical reduction factors (similar to partial factors), and a risk analysis matrix is used to search for a value of the reduction factor applicable to the specific design project being undertaken. This gives the design engineer the flexibility to reduce the partial factors if good ground investigation data and load testing are carried out, or increase them if designing in an unfamiliar soil deposit. The code itself gives advice on the elements of geotechnical risk that the designer must consider; in other words, they recognise that a 'one size fits all' approach is perhaps limited. Eurocode 7 aims to achieve a similar result by encouraging the designer to vary the characteristic values of soil properties in relation to the quality of the supporting data, while keeping the values of partial factors constant.

The discussion of the adhesion factor $\alpha$ for bored pile design is interesting. The parameter $\alpha$ relates to the soil deposit being studied; the value $\alpha=0.5$ is commonly used in London Clay. Increasing $\alpha$ to account for rate effects in clay might be warranted, but only if load-test data were also available (e.g. Burland et al., 1966). For example, previous use of 'constant rate of penetration' tests generally showed slightly higher values of $\alpha$ for London Clay (Patel, 1992). For static loading, $\alpha=0.7$ used in the Caltrans amendment, as noted by the discussers, does seem surprisingly high for a stiff clay (API, 1984); the overall reliability of the design will depend not only on this and the applied strength reduction factor, but also on the factors applied to loads. We understand that, in practice, the use of this value is often replaced by results from load testing.

\section{REFERENCES}

Aashto (2007) LRFD bridge design specifications. Customary US Units, 4th edn. American Association of State Highway and

Transportation Officials, Washington, DC, USA. API (1984) Planning, Designing and Constructing Fixed Offshore
Platforms. American Petroleum Institute, Washington, DC, USA.

Burland JB, Butler FG and Dunican P (1966) The behaviour and design of large diameter bored piles in stiff clay. Proceedings of the ICE Symposium on Large Bored Piles, London, UK, pp. $51-71$.

Caltrans (2011) California Amendments to Aashto LRFD Bridge Design Specifications, 4th edn. California Department of Transportation, Sacramento, CA.

FHWA (Federal Highway Administration) (2010) Drilled Shafts: Construction Procedures and LRFD Design Methods, Report No FHWA NHI-10-016. National Highway Institute, Washington, DC, USA.

Guha S (1995) Dynamic Characteristics of Old Bay Clay Deposits in the East San Francisco Bay Area. PhD thesis, Purdue University, Ann Arbor, MI, USA.

Paikowsky S (2004) Load and Resistance Factors for Deep Foundations, NCHRP Report 507. Transportation Research Board, Washington, DC, USA.

Patel D (1992) Interpretation of results of pile tests in London Clay. In Piling: European Practice and Worldwide Trends (Sands MJ (ed.)). Thomas Telford, London, UK, pp. 100110.

Poulos HG (2004) An approach for assessing geotechnical reduction factors for pile design. Proceedings of the 9 th Australia New Zealand Conference on Geomechanics, Auckland, New Zealand, vol. 1, pp. 109-115.

Standards Australia (2009) AS2159-2009: Piling: design and installation. Standards Australia, Sydney, NSW, Australia.

Vardanega PJ, Kolody E, Pennington SH, Morrison PRJ and Simpson B (2012) Bored pile design in stiff clay I: codes of practice. Proceedings of the Institution of Civil Engineers Geotechnical Engineering 165(4): 213-232. 